Отримано: 17 січня 2020 року

Прорецензовано: 23 січня 2020 року

Прийнято до друку: 29 січня 2020 року

e-mail: nataliplotnikova02@ukr.net

DOI: $10.25264 / 2519-2558-2020-9(77)-208-211$
Plotnikova N. V. Holy ritual bypass "Pocivannya" as a front concept of the microconseptosphere "Sviatki". Наукові записки Начіонального університету «Острозька академія»: серія «Філологія». Острог: Вид-во НаУОА, 2020. Вип. 9(77). С. 208-211.

\title{
HOLY RITUAL BYPASS “POCIVANNYA” AS A FRONT CONCEPT OF THE MICROCONSEPTOSPHERE "SVIATKI"
}

The article deals with the complex analysis of the concept "Pocivannya" of the microconceptosphere Sviatki projected for studying the peculiarities of its reflection in the synchronistical and diachronic aspects, as well as for clarifying of the specific character of its reflection in the hierarchical system of the linguistic world-image. Keeping within the limits of the lingvoculturological approach of the linguistic conceptology, in the research the notions such as conceptosphere, concept, conceptual microfield were considered.

In the structure of the microconceptosphere Sviatki 46 central concepts distributed to 10 conceptual microfields were distinguished. The appropriate field structure (nucleus, near-nucleus zone and periphery) of the microconceptosphere Sviatki was modeled and the hierarchical organization (superconcepts, presuperconcept, basic concepts, subconcepts) was presented. But the technique of the analysis of the lingvoculturological concepts suggested in this work consists of 3 stages: 1) formation of the nominative field of concept and definition of its nominative density; 2) description of the structural elements of the concept; 3) modeling of its field structure. During the analysis of every concept the means of its linguistic expression, including their paradigmatic and derivational peculiarities were characterized. The research of the central concepts of the microconceptosphere Sviatki permitted to discover the specific character of the national mentality of the Ukrainians within the limits of this fragment of the linguistic world-image.

Key words: linguistic culturology, microconceptosphere, concept, rite.

\author{
Плотнікова Наталя Володимирівна, \\ кандидат філологічних наук, доцент \\ Начіональний фармачевтичний університет
}

\section{СВЯТОЧНИЙ ОБРЯДОВИЙ ОБХІД ПОСІВАННЯ ЯК ПРИЯДЕРНИЙ КОНЦЕПТ МІКРОКОНЦЕПТОСФЕРИ СВЯТКИ}

Статтю присвячено комплексному аналізу концепту «Посівання» мікроконцептосфери Святки, який спроектований на вивчення його особливостей у синхронічному та діахронічному аспектах, а також на з'ясування специфіки його відображення в ієрархічній системі украӥнської мовної картини світу, шо передбачає вилучення інформачії про досліджуваний фрагмент концептуальної картини світу людини зі словників різних типів та етнографічних джерел (культурологічний аспект) і визначення особливостей його репрезентаиії в мові (семантичний аспект). Запропонована техніка аналізу лінгвокультурних концептів проходить у три етапи: 1) побудова номінативного поля концепту та встановлення його номінативної щуільності; 2) опис структурних елементів концепту; 3) моделювання польової структури.

Ключові слова: лінгвокультурологія, мікроконцептосфера, концепт, обряд.

For thousands of years, a series of holidays and ceremonies have formed in Ukrainians and their primary purpose is to influence magically the phenomena and forces of nature, to have a good harvest, breeding cattle, successful hunting and abundant prey in military campaigns. Among such ceremonies there are the holy ritual bypass that have taken place throughout the annual agrarian calendar. Calendar bypass are visits of each house and yard by special groups of participants which occur on certain calendar holidays and are conditionally divided into two types: 1) farm yards bypass; 2) bypassing the fields and pastures. The calendar bypass of the farm yards include those that occur in the winter during the Sviatki Holidays.

This material makes it possible to consider Christmas holidays or the Microconceptosphere Sviatki (MCS) as a complex system - a conceptual field that includes many concepts, that is, a macro-level conceptual field [8, p. 214]. The macro-level conceptual field, like the micro-level conceptual field, fully corresponds to all traditional canons of the field theory, that is, it has a structure in the form of a nucleus, a prenucleus zone and a periphery. Since the conceptual field is a large groupe of concepts, we consider it advisable to divide it into fragments - conceptual microfields (CMFs), which form a complex hierarchical system of interconnected fields, on the basis of which the linguistic picture of the world is formed, and combine homogeneous units in conceptual terms (simple concepts).

At the conceptual level, the concepts reflecting these cultural phenomena are divided into four CMFs: I. "Holy ritual bypass" - concepts Kolyaduvannye, Shchedruvannya, Pocivannya; II. "Holy Ritual Songs" - concepts Kolyadka, Shchedrivka, Christosanka, Vinshuvannye, Picivalna pisnya, Vodohresna pisnya; III. "Theatre performances" - concepts Koza, Malanka, Vertep; IV. "Anthropomorphic Mummers" - concepts Malanka, Did Moroz/St. Nicholas, Sniguronka.

The concepts within these CMFs do not exist outside the MCS Sviatki, so we refer them to the prenucleus zone of the macrolevel conceptual field, i.e. the MCS Sviatki. One of the fragments of such a conceptual microfield, the concept Pocivannya, is the subject of this study.

Detailed historic-ethnographic and cultural explorations devoted to the holy ritual bypass were made by L. Vinogradova [3], O. Kurochkin [5, p. 69-98], V. Chicherov [10], but there is no complex linguistic analysis of the tokens that represent the concept Pocivannya in the scientific literature.

The relevance of the topic of this article is due to the need to describe the concept Pocivannya according to the new linguistic paradigm, which is represented by the linguocultural trend in linguistics, taking into account both lingual and extralinguistic factors. 
The purpose of the article is to perform a linguoconceptual analysis of the linguistic expressions of the concept Pocivannya within the Microconceptosphere Sviatki.

For the study of the central concepts of MCS Sviatki we apply a complex methodology that combines elements of the semanticcognitive and the linguocultural analysis and is based on three stages:

1) construction of the nominative field of the concept and establishing its nominative density. The nominative field of a concept is a set of linguistic means that objectify a concept in a particular period of social development [6, p. 66]. The concept's nominative field is constructed by sampling dictionaries of different types and ethnographic sources of direct concept nominations, their synonyms and derivatives. Nominative density of the concept is proposed to be represented in digital equivalent, for which we introduce the concept of the nominative density coefficient, which is calculated by the formula Qnd = NFc: NFmcs, where Qnd is the coefficient of the nominal density, NFc is the total number of units of the nominative field of concept, NFmes is the total number of units of the nominative field of the microconceptosphere, which is 314 units.

2) selection and description of structural elements of the concept. According to the method of analysis of cultural concepts of Y. Stepanov, the structure of the concept are divided into two components - cultural and conceptual [9, p. 41]. The cultural component has three layers: a) historical, where we analyze the phenomenon from historical and ethnographic point of view; b) actual, where we analyze the existing synonyms and derivatives of the concept name; c) etymological, consideration of which makes it possible to determine the primary meaning of the concept name. The conceptual component is identified by analyzing the values of the main linguistic representations of the concept, which is carried out by the method of component analysis. According to the methodology of conceptual analysis of Z. Popova and Y. Sternin, we generalize and interpret the joint or similar in meaning sems of different linguistic representatives of one concept as cognitive features of the concept [6, p. 201], which is called the semantic element or component of the meaning of the concept. Similar semantic elements are also obtained through the analysis of all layers of the cultural component of the concept, generalizing and interpreting as the semantic elements the primary meaning of the concept name, the meaning that the concept has in the historical-ethnographic context, the lexical meanings of synonyms and derivatives.

3) modeling the concept's field structure. Dividing the conceptual field into the conceptual field of macro- and micro-level, A. Prikhodko includes to the first the set of concepts (in the article it is the MCS Sviatki), while the conceptual field of micro-level "can be conditionally considered as an idiofield of a separate concept" [8, p. 214]. So, the concept Pocivannya is a micro-level conceptual field, consisting of a hierarchy of semantic elements. The nucleus include the semantic elements that are highlighted during the analysis of the conceptual component. All other components of the meaning, depending on the frequency of their use, as well as the scope, belong to the prenucleus or peripheral zones. The field structure of the concept is presented taking into account the features of different periods.

Cultural-linguistic analysis of the concept Pocivannya. I. The cultural component of the concept. A) historical layer. It is believed that the rite Pocivannya has come to us from pre-Christian times, because our ancestors celebrated the New Year not in the winter, but in the spring, and therefore the sowing ceremony is associated with the hope of a good harvest. According to A. Afanasyev, "the rite marks the spring insemination of the mother Earth, who marries with the enlightened sky, and the grain is the emblem of fruitful seed of rain and sunlight" [1, p. 746]. So, it is legitimate to think that it is a simulation of sowing.

Traditionally, the sowing rite is performed as it is described by O. Potebnya: In Little Russia, on the New Year, as the sun rises, boys, young men and old people go to sprinkle different grain from their bags or mittens" [7, p. 60], that is, the sowers in each house sprinkle with the grain of the owner and the house, saying: "Fortunately, for health and for the new summer. Bear, O God, of rye, of wheat, and of all pasture". Undoubtedly, all sowers were received as the most desirable guests and were genuinely treated with apples, pies, dumplings, were donated small money, "scattered grains were collected with special remarks and stored until spring sowing" [7, p. 60].

The sowing rite was preserved as a remnant of pagan times, as indicated by the archaic elements in its composition that have agricultural character. The basis of this bypass was "the magical idea of the "first day", according to which the wishes expressed in the period of New Year were to become reality, give tangible positive effects" [5, p. 307]. With the withering away of agrarian beliefs, this rite is turned into folk games and in such form exists today, which deprives scientists of the opportunity to study it. That is why in $1965 \mathrm{O}$. Day assured that there are not still materials in science that would testify to the content and nature of these rituals in the pre-Christian and early Christian times. Such materials didn't appear in the modern period.

So, considering the holy bypass Pocivannya as a concept, we note that the basis for its formation was the mythological worldview of the pagans, that is why depending on the role in the structure of consciousness we define it as a mythological concept; from the point of view of the subject conceptualization it is an ethno-concept; based on the object conceptualization parameter it is cultural concept.

Historical layer analysis of the cultural component of concept Pocivannya revealed its semantic elements: "sacrifice", "joy",

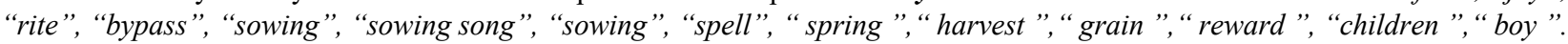
At the lexical level, this mythological concept is represented by the corresponding token - Pocivannya.

B) etymological layer. The noun pocivannya comes from the verb cismu (to sow), whose etymology is quite transparent, because it has the same meaning in all Slavic languages. The etymology of the verb сіяти is represented in the table:

\begin{tabular}{|c|l|c|}
\hline Token & \multicolumn{1}{|c|}{ Slavic languages } & \multicolumn{1}{|c|}{ Non Slavic languages } \\
\hline Сіяти & $\begin{array}{l}\text { R. сеять, br. сеяць, or. съзяти, pol. siać, ch. siti, slov. siat', bulg. } \\
\text { се́я, [4, p. 259]. }\end{array}$ & Related to lit. séti «сіяти», lat. sero «сіяти» [4, p. 259]. \\
\hline
\end{tabular}

Since the etymology of the verb сіяти is rather transparent, the analysis of the etymological layer of the cultural component of the concept Pocivannya within the framework of the MCS Sviatki has revealed only one of its semantic elements: «to sow».

C) actual layer. Lexical signs. The dictionary of Ukrainian language synonyms does not fix synonyms of the token pocivannya, but the name of the festive sowing rite has semantic synonyms that are recorded in historical and ethnographic sources, in particular, the tokens pocipannya [5, p. 313] and zacivannya [5, p. 313]. 
Most ethnographers note that the rite of sowing on the first day of the New Year was the most common and still remains common in Ukraine. The noun zacivannya as the name of the New Year's rite was formed from the verb zacivati in the last sixth meaning, "Sprinkle with grain in the house, in the room, congratulating on the New Year" [2, p. 421], therefore, we consider it more legitimate to use for this rate the name pocipannya, used in the researches by O. Voropay, S. Kylymnyk, V. Suprunenko, since the last meaning of the verb zacivati is the first meaning of the verb pocivati: "Scatter grain in the house, in the room, greeting the hosts with the New Year» [2, p. 1077]. So, the nomination pocivannya will be more logical, though, the basis of both zacivannya and pocivannya nominations is the action that takes place on that day. That is, the scattering of grain around the house or the room simulate the sowing of a field.

With regard to the name of pocipannya, its occurrence is related to the method of performing the rite. According to some ethnographers, the grain is not only sown during the ceremony, but sprinkled on it, in particular, the boys on New Year's Day, when the sun rises, go around the houses and sprinkle all the grain. But this name is rarely used.

The paradigmatic aspect of the study of the mythologem Pocivannya verbalizers revealed the synonymic row POCIVANNYA ZACIVANNYA - POCIPANNYA with the common archives of ceremonial bypass. Considering the scarcity of token pocipannya and the logic of using of the token pocivannya instead of zacivannya, we consider like the dominant of this synonymous row the token pocivannya, which is the name of the concept.

The analysis of the actual layer of the cultural component of the concept Pocivannya within the framework of the MCS Sviatki made it possible to identify its semantic elements: «rite», «bypass». The number of units of the nominative field of the concept Pocivannya is 3 , and the coefficient of the nominal density is 0,009 , which indicates the conscious existence of this concept within the limits of the MCS Sviatki, and its insufficient communicative relevance.

II. Conceptual component of concept. Linguistic representatives of the mythologem Pocivannya are the tokens pocivannya, zacivannya, pocipannya. Concerning the noun pocivannya it is noted in lexicographic dictionaries: «Pocivannya-ethn. old. Action that means to sow 1.» [2, p. 1077]. The verb pocivati in the first sense has the following definition: «ethn., old. Scatter grain around the house, room, greeting the hosts with the New Year » [2, p. 1077], therefore, it is considered possible (by analogy with the tokens kolyaduvannye and shchedruvannya) to distinguish in the semantic structure the token pocivannya LSV a New Year's ritual bypass, accompanied by the scattering of the grain in the house or room and greetings of the hosts with the New Year.

The noun zacivannya has the following definition in the dictionaries: «Action that means to sow» [2, p. 421]. The verb to sow has the following meanings in modern lexicographic sources: 1) to throw grain, the seeds in the cultivated land, in some way shattering, scattering them; 2) sowing grain, seeds to occupy any land // Cover something (about plants); 3) appearing, growing on the skin, cover it (about mustache, beard, freckles); 4) cover something, some surface with something scattered; 5) start to sow (about rain, etc.); 6) ethn., old. Sprinkle with grain in the house and the room, congratulating the New Year [2, p. 421]. Given the fact that none of the dictionaries indicate which meaning of the verb to sow is motivating for the noun zacivannya, we conclude that all mentioned meanings of the verb to sow are related to the newly formed noun, so in the semantic structure of token zacivannya we distinguish the corresponding LSVs. Analyzing the selected LSVs, we pay special attention to the meaning of the word zacivannya, which is connected with the calendar ritual of the Ukrainians during the winter holidays, in particular the LSV New Year's ritual bypass, accompanied by scattering the grain in the house and rooms and New Year's greetings.

«Pocipannya - action with the meaning to sprinkle» [2, c. 1077]. The noun pocipannya has the following definition in the dictionaries: 1) throw, scatter anything loose; pour; 2) spoken 1. Give loose food to some animals, usually birds; 3) pour some time; 4) to cover with a layer of something loose // to shake, to scatter something on the surface of something // to throw, to direct in large quantities to someone, something, to something; 5) start pouring, scattering, throwing away, etc. something loose or small; 6) start to crumble, fly out of large numbers; 7) spoken 1. Talk very fast // start playing at a very fast pace; 8) start to go, pour in (about light snow or hail), pour (about heavy rain); 9) spoken 1. To go fast, to run one after another like a large mass (about many); 10) ethn., old. According to ancient folk custom, to scatter grain in the house, in the room, greeting the owners with the New Year [2, p. 1077]. Given that none of the dictionaries indicate which meaning of the verb to sprinkle is motivating for the noun pocipannya, we conclude that all the meanings above of the verb to sprinkle have to do with the newly formed noun, so in the semantic structure of the token pocipannya we distinguish the corresponding LSVs. Analyzing the selected LSVs, we pay special attention to the meaning of the word pocipannya, which is connected with the calendar rite of Ukrainians during the winter holidays, and given the fact that during the sowing ceremony, grain is not only symbolically sown, but sprinkled with, we believe that LSV (in the semantic structure of token pocipannya) should look like this: New Year's ceremonial rite, accompanied by the sprinkling with grain of hosts, houses, rooms and greetings to the owners with the New Year.

Set of mentioned LSV is given in the table:

\begin{tabular}{|c|l|l|}
\hline $\begin{array}{c}\text { LANGUAGE } \\
\text { REPRESENTATIVE }\end{array}$ & \multicolumn{1}{|c|}{ LSV } & \multicolumn{1}{|c|}{ SEMS } \\
\hline pocivannya & $\begin{array}{l}\text { New Year's rite, followed by scattering grain in the } \\
\text { house, room and greetings to the hosts on the New } \\
\text { Year's Day. }\end{array}$ & $\begin{array}{l}\text { 1. Rite bypass. } \\
\text { 2. New Year's rite bypass. } \\
\text { 3. Spread the grain around the house or room. } \\
\text { 4. New Year's greetings. }\end{array}$ \\
\hline zacivannya & $\begin{array}{l}\text { New Year's rite, accompanied by the sprinkling with } \\
\text { grain of hosts, houses, rooms and greetings to the hosts } \\
\text { on the New Year's Day. }\end{array}$ & $\begin{array}{l}\text { 2. New Years. } \\
\text { 3. Sprinkling with grain houses, rooms and the } \\
\text { hosts. } \\
\text { 4. New Year's greetings. }\end{array}$ \\
\hline
\end{tabular}

Accordingly, in the minds of modern Ukrainians, the mythological concept Pocivannya as a constituent of the MCS Sviatki contains the semantic elements «rite», «bypass», «sprinkling», «sowing», «congratulations on the New Year».

The complex analysis of the concept Pocivannya as a component of MCS Sviatki contributed to the selection of its dominant semantic elements, which made it possible to consider the field organization of this concept: 


\begin{tabular}{|c|c|}
\hline PERIOD & COMPONENTS OF MEANINGS \\
\hline Pre-Christian period & 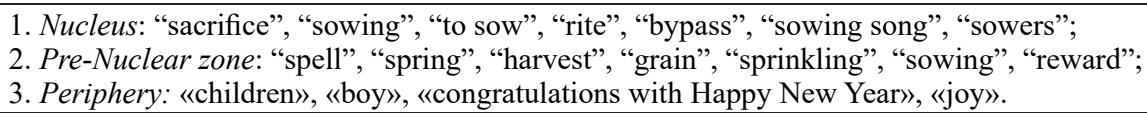 \\
\hline Christian period & $\begin{array}{l}\text { 1. Nucleus: "Sowing", "to sow", "rite”, "bypass", "sowing song”, "sowers"; } \\
\text { 2. Nuclear zone: "harvest", "'grain", "sprinkling", "sowing", "sacrifice", "reward"; } \\
\text { 3. Periphery: «children», «boy», "spring", «congratulations with Happy New Year», «joy». }\end{array}$ \\
\hline Modern period & $\begin{array}{l}\text { 1. Nucleus: "rite", "bypass", "sowing song", "sowers"; } \\
\text { 2. Nuclear zone: "Happy New Year" greetings, "grain", “sprinkling”, “sowing”, "reward"; } \\
\text { 3. Periphery: «children», «boy», «joy». }\end{array}$ \\
\hline
\end{tabular}

Analyzing the conceptual structure of the concept Pocivannya with respect to the field organization, we conclude that the nuclear components of meaning make up $\approx 33 \%$. Over the centuries, this concept has undergone changes in the nuclear zone, in particular, the conversion of holy ritual bypass into folk games led to a loss of motivation for some rites, which led to the disappearance of the meaningful elements of "sowing", "to sow" in the conceptual structure of the mythological concept Pocivannya.

The percentage expression of the meanings elements in the pre-nucleus zone of the concept Pocivannya is $\approx 41 \%$. Changes have also taken place in this zone over the centuries, in particular, the conversion of the pagan worldview to a Christian one is accompanied by the loss of the semantic element "spell", and the transfer of the New Year's date from spring to winter contributes to the transition of the "spring" meaning component to the periphery zone and leads to its decline. The semantic element "harvest" disappears from the pre-nucleus zone of conceptual structure of the mythologem Pocivannya in connection with the extinction of agrarian beliefs, that is, the loss of understanding of sowing as an imitation of spring sowing leads to the disappearance of the hope that this sowing promotes the harvest.

The periphery zone of the mythologem Pocivannya contains $\approx 25 \%$ of the meaning elements. This zone is also characterized by changes, such as the meaningful element «New Year's greeting» moves from the periphery to the pre-nucleus zone at the present stage.

The results of the studying of the mythologem Pocivannya, obtained by means of component, etymological and historicalcultural analysis, make it possible to conclude that this concept belongs to the significant in Ukrainian culture and in the life of Ukrainians.

The proposed method of complex analysis of cultural concepts can be used in studying other similar concepts, which is promising in the modern period, when we see an increase in attention to the national identity of Ukrainian culture.

\section{References:}

1. Афанасьев А. Н. Поэтические воззрения славян на природу: В 3 т. Москва: Типографія Грачева, 1865-1869. Т. 3. 1869. 818 с. 2. Великий тлумачний словник сучасної української мови / [уклад. і голов. ред. В. Т. Бусел]. Київ; Ірпінь: ВТФ «Перун», 2007. $1736 \mathrm{c}$.

3. Виноградова Л. Н. Зимняя календарная поэзия западных и восточных славян: Генезис и типология колядования. Москва: Наука, 1982. 256 с.

4. Етимологічний словник української мови: В 7 т. / АН УРСР, ін-т мовознавства ім. О. О. Потебні. Київ: Наукова думка, 1982-2006. T. 3. 1989. 552 c.

5. Курочкін О. В. Новорічні свята українців: традиції і сучасність. Київ: Наукова думка, 1978. 191 с.

6. Попова 3. Д. Когнитивная лингвистика. Москва, 2007. 314 с.

7. Потебня А. А. Объясненія малорусскихъ и сродныхъ народныхъ пъсенъ. ІІ. Колядки и щедрівки. Варшава: Типографія М. Земкевича, $1887.810 \mathrm{c}$.

8. Приходько А. М. Концепти і концептосистеми в когнітивно-дискурсивній парадигмі лінгвістики. Запоріжжя: Прем’єр, 2008. $332 \mathrm{c}$.

9. Степанов Ю. С. Константы: Словарь русской культуры. Опыт исследования. Москва, 1997. 824 с.

10. Чичеров В. И. Зимний период русского земледельческого календаря XIV-XIX вв. М.: Из-во АН ССCР, 1957. 236 с. 